"Corruption, political instability and their impact on investment: An FMOLS approach"

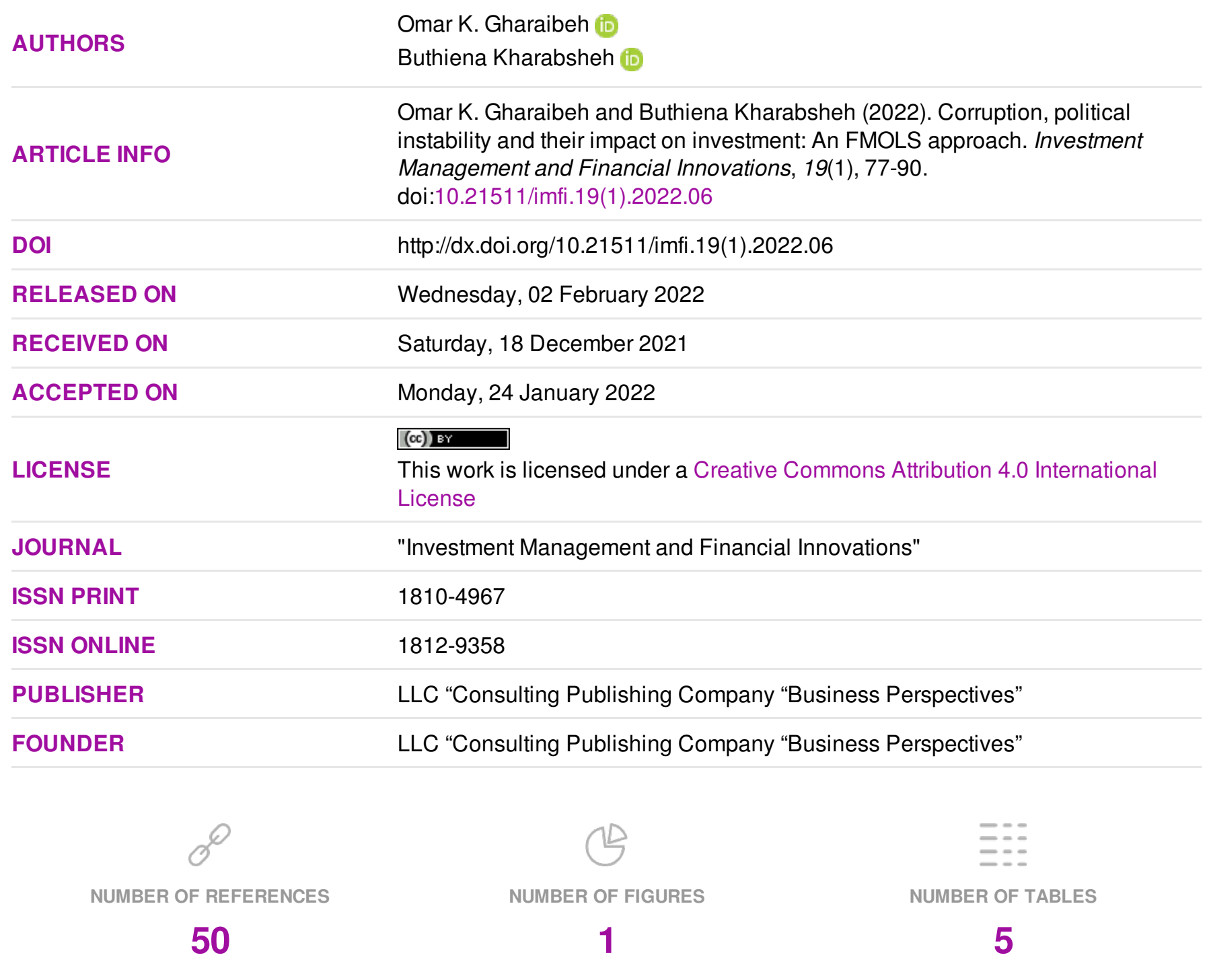

(C) The author(s) 2022. This publication is an open access article. 


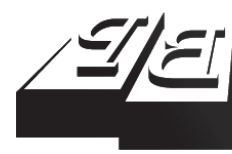

BUSINESS PERSPECTIVES

(O)

LLC "CPC "Business Perspectives" Hryhorii Skovoroda lane, 10 Sumy, 40022, Ukraine www.businessperspectives.org
Received on: $18^{\text {th }}$ of December, 2021 Accepted on: $24^{\text {th }}$ of January, 2022 Published on: $2^{\text {nd }}$ of February, 2022

(c) Omar K. Gharaibeh, Buthiena Kharabsheh, 2022

Omar K. Gharaibeh, Associate Professor, Finance and Banking, School of Business, Al-alBayt University, Al-Mafraq, Jordan. (Corresponding author)

Buthiena Kharabsheh, Associate Professor, Finance and Banking Sciences, Faculty of Economic and Administrative Sciences, Yarmouk University, Irbid, Jordan.

\section{CORRUPTION, POLITICAL INSTABILITY AND THEIR IMPACT ON INVESTMENT: AN FMOLS APPROACH}

\begin{abstract}
Due to the lack of studies in the financial literature on indicators of corruption and political instability relative to investment, this paper is considered one of the first studies that examines the impact of two-corruption indicators and political instability on investment in Jordan over the period 1987-2020. Using Fully Modified Ordinary Least Squares (FMOLS) based on annual data, the corruption effect as measured by the corruption score index is a negative and statistically significant impact on investment in Jordan. The second measure of corruption, which is the corruption rank index, confirmed the previous result that corruption has a negative and statistically significant effect. Political instability measured in this study as a dummy variable by wars in the region has a positive and statistically significant effect on investment. For macroeconomic variables, the results show that current government expenditure and interest rate have a negative and significant impact on investment in Jordan. The interest rate factor was the highest coefficient among the negative effects. The study also shows that the investment in Jordan is positively and significantly affected by gross domestic product, imports and local revenue. The gross domestic product showed the highest coefficient among the positive effects. This study concludes that policy makers attempt to apply transparency and minimize the corruption through flexibility, facilitation of procedures and reduced transactions using automation. The study also concludes that decision makers should rationalize current government expenditure and direct banks in Jordan to give greater priority to credit facilities for productive sectors.
\end{abstract}

Keywords

investment, determinants, FMOLS, corruption, wars, Jordan

JEL Classification E22

\section{INTRODUCTION}

Jordan has witnessed many economic changes internally and political changes externally in the region that affected the levels of investment. It has been noted that the investment rate has fluctuated significantly during the past decades. Based on the data of the Central Bank of Jordan website ${ }^{1}$, the percentage change in investment indicator shows that it is unstable and fluctuates from -0.13 to 0.64 over the period 1987-2020. Recently, based on the report of the Jordan Strategic Forum is issued in June 2021 on the Jordanian economy for the year 20162020 , the number of newly established companies decreased from 7,061 companies in 2016 to 4,134 companies in 2020. The number of companies listed on the Amman Stock Exchange decreased from 227 companies to 174 companies during the same previous years. It is well known that investment plays a major role in increasing exports and production rates. Investment affect in reducing unemployment levels and plays an important role in increasing development rate. In ad-

1 https://www.cbj.gov.jo/ 
dition, decision makers realize that increased volatility in investment can negatively affect the performance of the economy. Therefore, examining the factors that affect investment in Jordan is an important issue for the economy.

Drabek and Payne (2002) indicate that fluctuations in investment is related to corruption reflecting the extent of inflexibility, difficult procedures and high transaction costs as measured by corruption indicators. Corruption is usually defined as the misuse of public power to achieve private benefits (Qureshi et al., 2021). Prior studies have proven that corruption is one of the important obstacles to investment progress. Higher corruption means weak institutional quality, governance and regulation. Despite that, corruption might inflate economic and investment values, the long-term effect could destroy value (Dabour, 2000; Mo, 2001; Rock \& Bonnett, 2004). In 1990, Jordan ranked 30th out of 180 countries, but in 2020, it ranked 60th out of 180 countries. The corruption-rating index in Jordan decreased from 30 to 60 globally. This problem, which began to appear in the increase of corruption and the decrease in the number of companies, is the motivation for this study to examine the impact of corruption on investment in Jordan.

Jordan has an important geopolitical position in the Middle East, which is considered a politically stable country. During the past period, the Middle East has witnessed several political conflicts such as the Gulf War (1990), the Iraq War (2003), the Arab Spring in 2010 followed by the latest Syrian civil war. It is well documented in the literature that political instability can have several negative consequences on the economic development (Asteriou \& Price, 2001; Afolabi \& Abu Bakar, 2016). It adversely influences the economy by increasing uncertainty related to the future policies and outcomes. Political instability leads to unfavorable investment environment with a lower speed of economic development and poor economic conditions (Alesina et al., 1996). However, political instability in the Middle East forced many investors in those countries, especially the Palestinians of Kuwait and the Iraqis migrated to Jordan to protect their investments. This political factor on investment is considered the second motivation for conducting the current study.

There are macroeconomic factors that play a role in investing in the financial literature. These internal economic factors such as growth domestic product (GDP), imports (IMP), or factors related to fiscal policy such as current government expenditure (EXP) and local revenue (LR) or factors related to monetary policy such as interest rate (INT) and credit facilities (FAC).

This study aims to examine the impact of these macroeconomic factors on investment in Jordan, along with the indicators of corruption in Jordan and the factor of political instability in the Middle East. In particular, this study will answer the following questions: Does corruption have a statistically significant effect on investment? Do regional wars have a statistically significant impact on investment? Do macroeconomic variables such as GDP, IMP, EXP, LR, INT, FAC have a statistically significant effect on investment?

This study is important due to the following reasons. First, this is the first study that discusses the impact of various factors such as the degree of corruption, political instability in the region, and macroeconomic factors on investment. Secondly, previous studies applied various models such as the ordinary least square (OLS) model, cointegration models, and others. However, no study uses fully modified ordinary least squares (FMOLS). The current study applies the FMOLS model, which provides more accurate results and controls for many econometric issues in the analysis. Thirdly, this study is also important because it examines the factors affecting investment over a long period extending from 1987-2020. Finally, previous studies on investment are relatively limited. Most of the previous studies are restricted to a few countries focusing on the developed countries and minimal for developing countries. This study will enrich the financial literature at the level of developing countries. 


\section{LITERATURE REVIEW AND HYPOTHESES}

Extensive literature exists to identify the key determinants of investment. Corruption appears as one of the most debated variables in the literature. In this regard, two competing hypotheses explain this effect. The first is that corruption has a negative (sands the wheels) effect on investment (Gould \& Amaro-Reyes, 1983; Mauro, 1995). They claim that corruption is a discouraging aspect that leads to higher costs of production, poor allocation of resources, and higher rates of poverty. The pioneered work of Mauro (1995) has reported early evidence on the negative relationship between corruption and investment using cross-country data. Their study found that poor countries tend to have more corruption, bureaucracies, and political instability where these variables tend to slow down growth rates. Li et al. (2000) examine how corruption and other institutional variables are related to income distribution and growth. They found a negative effect between corruption and growth, particularly in countries with higher assets inequality. Applying the Autoregressive Distributed Lag Model (ARDL), Drebee et al. (2021) examined the determinants of investment in the Iraqi agriculture sector covering the period 2004-2019. Based on the long term, they showed that inflation and corruption have a negative and significant effect.

The competing view suggests that the greasing hypothesis (Leff, 1964; Huntington, 2002; Heidenheimer et al., 1989) supports the notion of the positive effect of corruption on investment. Leff (1964, p. 9) argued, "Corruption can help development by making possible a higher rate of investment than would otherwise be the case". Leff explains that corruption might lead to enhance innovation and encourage competition. Further, Leff (1964) contends that corruption might reduce the uncertainty that results from heavy government intervention in the economy and frequent changes in its policies and decisions. Lui (1985) indicates the positive effect of corruption through the queue model. The presence of corruption is desirable in order to reduce the time required to process the work. In addition, corrupt agents might become more efficient, taking the decisions faster and with less complexity. Other sup- porting studies (Beck \& Maher, 1986; Acemoglu \& Verdier, 1998) point out that corruption could speed decisions and save time for economic transactions, through illegal payments (bribes). Jiang and Nie (2014) find that corruption in China advances the production and allocation of resources. Huang (2016) also found similar positive evidence in South Korea. However, a contradictory result was found between developed and developing countries. In developed countries, Qureshi et al. (2021) show that the corruption negatively affects Foreign Direct Investment (FDI) and economic progress, while positively affecting investment in developing countries.

Political stability is an important factor that has a direct impact on the investment level and development. In the finance literature, the capital tends to move and prefers safe and stable investment environments. Countries with political conflicts are usually characterized by poor institutional quality, weak governance, and exposure to higher uncertainty (Murad \& Alshyab, 2019). For such reasons, investors tend to direct their capital outside for a more attractive investment environment. At the level of the Gulf Cooperation Council countries, Jaara (2021) point out that the Arab Spring has negatively affected the performance of banks. Further, in countries with political instability, it is highly likely to have strikes, violence, social crimes, and government failure. Such conditions have a direct effect on business and investment. In this context, Murad and Alshyab (2019) indicate that external political instability has a positive effect in border countries, while it has a negative effect when there is internal political instability.

In this regard, the literature has extensively tackled the factors that attract FDI. The answer can be traced back to the location theories developed by Vernon (1974) and Dunning (1973). These theories stress the importance of resources availability, advanced infrastructure, lower labor cost in addition to the political environment, in the hosting country, to attract such capital inflows. The empirical literature highlights the effect of FDI on economic growth. FDI has been regarded as the main source of capital in developing nations, particularly, for investment. FDI positively boosts economic growth through offering new job opportunities, increasing productivity by enhancing com- 
petition, and the transfer of skills and technology (Yousaf et al., 2008; Chung, 2001; Rani \& Batool, 2016). Zhang (2001) tested this relationship in China, using a long period from 1960 to 2001 . The results reveal that FDI positively boosts economic growth. Rani and Batool (2016) examine how political instability and FDI affect economic growth in Pakistan. The ARDL estimation method is applied over the period 1980-2013. In the short run, political instability has no significant effect, however, in the long run, the effect is significantly negative. Further, the study documents a positive link between FDI and growth in both the short and long run. This study includes political instability in the region taking the wars in the region as the main indicator and examines how these political conflicts affect investment in Jordan.

Prior literature argued that macroeconomic variables are among the most important determinants of investment (See, for instance, Ucan, 2014; Duruechi \& Ojiegbe, 2015; Rani \& Batool, 2016; Sukharev, 2021). Based on cross-country data, Salahuddin et al. (2009) proposed that investment can be positively affected by the GDP, lagged investment, trade openness, domestic savings, and institutional development, while negatively affected by private sector credit, foreign debt serving, and foreign aid. Ucan (2014) investigates the determinants of investment for G7 countries. They show that private investment is positively and significantly affected by per capita GDP and interest rate. Similarly, Duruechi and Ojiegbe (2015) investigate the effect of macroeconomic variables on the investment of the Nigerian economy over the period of 1990-2013. Using the Johansen Co-integration test, Duruechi and Ojiegbe (2015) provide the evidence of a longrun relationship between investments, government expenditure, inflation rate, interest rate, and exchange rate. Based on the Pairwise Granger causality, Duruechi and Ojiegbe (2015) find causality running unidirectional from government expenditure to investment. Recently, Sukharev (2021) shows that investment is affected by a decrease in the interest rate, an increase in the monetization of the economy, and a controlled devaluation.

In Jordan, Bader and Malawi (2010) examined the effect of real interest rate (RR) and gross domestic product (GDP) on the investment level using a co-integration analysis. They showed that RR has a significant and negative effect on investment, while investment is not significantly and positively affected by GDP. Their finding related to RR is consistent with economic theory. Abu-Lila (2021) found that the investment in Jordanian productive sectors is positively and significantly affected by real value of credit facilities and real value of sector's production. However, the investment is negatively and significantly affected by the real interest rate.

The purpose of this study is to investigate the impact of corruption, political instability and macroeconomic variables on investment in Jordan over the period 1987-2020. Based on the above discussion, the following hypotheses are proposed:

$H_{1}: \quad$ Corruption has a statistically significant effect on investment.

$\mathrm{H}_{2}$ : Regional wars have a statistically significant effect on investment.

$\mathrm{H}_{3}$ : Macroeconomic variables have a statistically significant effect on investment.

\section{DATA AND METHODOLOGY}

\subsection{Data and variables}

The data used in this study are downloaded from the Central Bank of Jordan website. The dependent variable used in this study is a gross fixed capital formation by economic activity current prices (GFCF) that represents the broad investment (INV) in the Jordanian sectors. This indicator statistically measures the value of new or existing fixed asset acquisitions by government, businesses, and households (excluding their unregistered enterprises) less fixed asset disposals. Typically, GFCF time series data is used to analyze trends in investment activity over time. This indicator GFCF was used as it shows something about how much new value added in the economy is being invested rather than consumed.

On the other hand, two indicators of corruption, which are the corruption score (SC) and the corruption rank (RA), have been used as the first independent variable in the current study. The 
Corruption Score Index extends from zero to one, and the closer the ratio of the state to one, the lower the corruption in that state, and vice versa. The Corruption Rank Index sorts countries based on how corrupt their public sector is supposed to be. A country's ranking determines its position relative to other countries in the index. Corruption scores and corruption rank indices have not been used extensively in the previous financial literature. The two corruption variables are downloaded from the website of Transparency International, the global coalition against corruption (Transparency International, n.d.).

The second independent variable applied in this paper is War Dummy variable (DUM). The dummy variable was taken to study the impact of the war on investment in Jordan. The 1990 Kuwait war and the 2003 Iraq war were adopted for this purpose. The period of war is usually reflected in the post-war years. Therefore, a period will be determined, which is the year of the war and six years after the war. For example, the effect of the Kuwait war period was determined from 1990 to 1996, and the effect of the Iraq war period was determined from 2003 to 2009. Finally, six macroeconomic independent indicators or variables were used as a control variable, namely, the growth of domestic product at market prices (GDP), imports (IMP), domestic revenues (LR), current expenditure (EXP), weighted average interest on credit and loan facilities (INT), credit facilities (FAC). This study includes annual data extending from 1987 to 2020 , and this period was chosen because the investment in Jordan began fluctuate after 1987.

Table 1 provides a summary of the statistics for the gross fixed capital formation by economic ac- tivity that represents the investment (INV) in the Jordanian sectors. The first independent variable is corruption measured by SC and RA, while the second independent variable is War Dummy variable DUM. The remaining six independent variables are macroeconomic factors, namely GDP, IMP, LR, EXP, INT, and FAC. The averages (Av) of all these variables are relatively larger than the standard deviation (S.D) except of EXP, INT and FAC. This means that most of these indicators in Jordan fluctuate significantly during this period. The maximum (Max) and minimum (Min) values are relatively large, and this confirms large fluctuations in these indicators. On the other hand, EXP, INT, and FAC indicators indicate that the current government expenditures, interest and credit facilities in Jordan are large and relatively stable. The skewness (Skew) is positive in all indicators except of GDP, kurtosis (Kurt) is around three in majorities of cases. Finally, the number of observations for each variable is 34 .

Figure 1 illustrates the percentage change in the investment indicator over the full sample period. The indicator of the percentage change in investment is not stable and increases sharply and shows an upward trend after the war years (the first Gulf War in 1990 and the war on Iraq in 2003). These wars forced investors and capital owners in those countries (Kuwait and Iraq) to flee from those countries, migrate to Jordan, and transfer their capitals or investments. This reflects during 6 years immediately following the war. Therefore, the idea of the war dummy variable came from Figure 1. The dummy variable was taken into account in the year of the war and the period following the war over a span of six years. For example, the number of one was placed in 1990 to 1996, which is the

Table 1. Descriptive statistics

\begin{tabular}{|c|c|c|c|c|c|c|c|}
\hline Variables & \%Av. & \%S.D. & \%Max. & \%Min. & Skew. & Kurt. & Obs. \\
\hline Investment (INV) & 0.09 & 0.18 & 0.64 & -0.13 & 1.44 & 4.55 & 34 \\
\hline Corruption Score (SC) & 0.15 & 0.19 & 0.53 & 0.04 & 1.21 & 2.49 & 34 \\
\hline Corruption Rank (RA) & 0.03 & 0.11 & 0.33 & -0.18 & 0.64 & 4.16 & 34 \\
\hline War Dummy Variable (DUM) & 0.42 & 0.50 & 1.00 & 0.00 & 0.31 & 1.09 & 34 \\
\hline Gross Domestic Product (GDP) & 0.04 & 0.04 & 0.14 & -0.11 & -0.85 & 8.28 & 34 \\
\hline Imports (IM) & 0.05 & 0.13 & 0.45 & -0.25 & 0.83 & 4.55 & 34 \\
\hline Local Revenues (LR) & 0.09 & 0.10 & 0.38 & -0.04 & 1.06 & 3.50 & 34 \\
\hline Current Expenditure (EXP) & 0.08 & 0.07 & 0.24 & -0.02 & 0.61 & 2.87 & 34 \\
\hline Interest rate (INT) & 0.10 & 0.01 & 0.13 & 0.08 & 0.80 & 2.93 & 34 \\
\hline Credit Facilities (FAC) & 0.10 & 0.07 & 0.26 & 0.02 & 1.01 & 3.25 & 34 \\
\hline
\end{tabular}




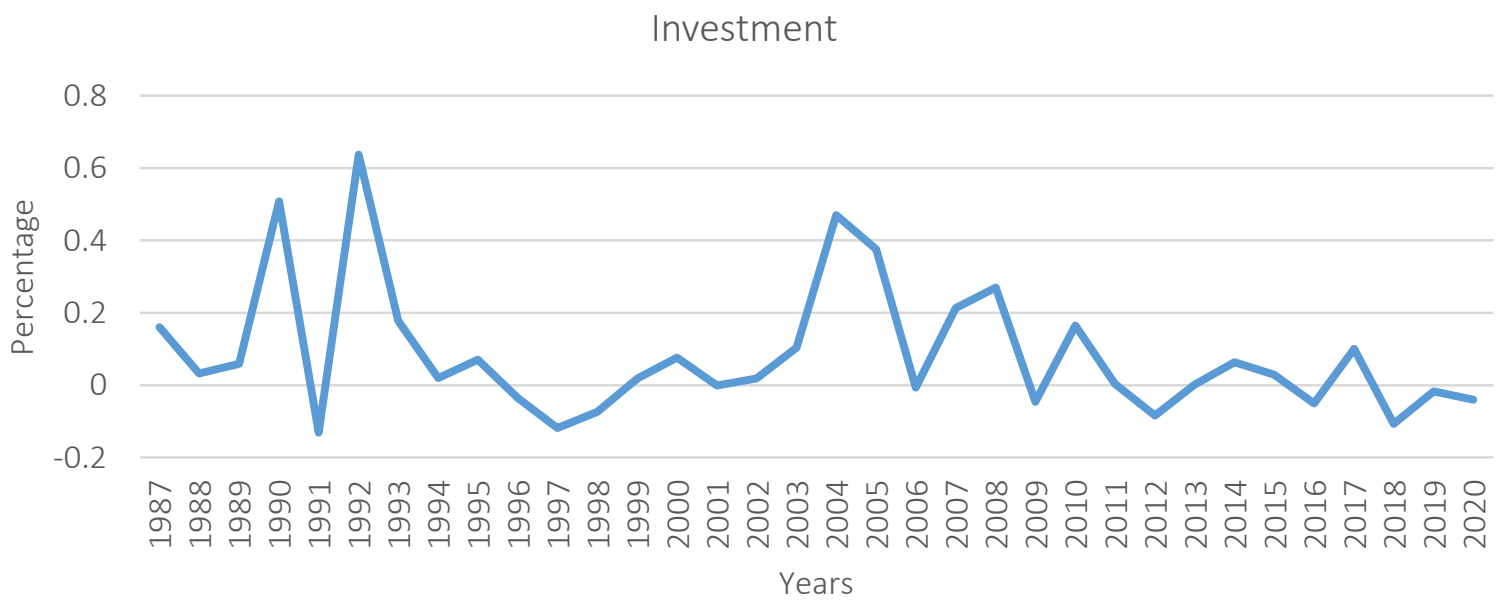

Figure 1. Investment indicator

first Gulf War in 1990, and the number of one was placed in the year 2003 to 2009 , which is the war on Iraq, while the remaining years were set to zero.

The fully modified least square approach (FMOLS) is used to examine the long-run relationship of the gross capital formation index and a set of important variables. To complete this model, three different steps were applied as follows: First, stationary testing and integration of all variables are applied. To test for stationarity, the unit root test either Augmented Dickey-Fuller Test proposed by Dickey and Fuller (1979) or Phillips-Perron Test presented by Phillips and Perron (1988), known as $\mathrm{ADF}$ and PP, respectively, are used in this study. Second, to demonstrate any evidence of a longterm equilibrium relationship between the variables, this study applied the Johansen co-integration test to the data. Third, to assess the impact of various independent variables on investment, the FMOLS technique proposed by Pedroni (1996) was employed.

\subsection{Methodology}

\subsubsection{Unit root test}

This study uses 34-year annual time-series data of Jordan from 1987 to 2020. In most cases, time-series data suffers from the problem of non-stationarity or trend behavior. Hence, it is important to eliminate such a random behavior to obtain correct results. Furthermore, in the absence of stationary data and the presence of the co-integrated vector(s), Perron and Phillips (1986) point out that the results of time series models may be spurious. In this context, this paper firstly needs to test the stability of the data to determine the stationarity at levels, first or second difference. This step guides this study in defining a suitable model for data analysis. The study implements two unit root tests: ADF and PP of the investment model to verify that the long-run relationship of time series variables is stationary. The first unit root test is the ADF as follows:

$$
\Delta Y_{t}=\alpha_{0}+\alpha_{1} Y_{t-1}+\sum_{j=1}^{k} d_{j} \Delta Y_{t-j}+\varepsilon_{t},
$$

where $\Delta$ - the difference operator; $Y_{t}$ - a time series; $\alpha_{0}$ - the Constant, $k$ - the optimal number of lags for the dependent variable; $\varepsilon_{t}$ - the error term.

The ADF test helps determine if coefficient estimates are equal to zero, and this test presents cumulative distribution of the ADF statistics. A variable is considered stationary when the parameter value is less than the critical values.

The second unit root test is the PP, and this test is based on $t$-statistics related to the estimated coefficient of $\rho^{\star}$ as follows:

$$
\Delta Y_{t}=\alpha+\rho \cdot Y_{t-1}+\varepsilon_{t} .
$$

\subsubsection{Johansen co-integration approach}

The second step in this study uses time-series co-integration test proposed by Johansen (1988) and Johansen and Juselius (1990). Co-integration is when two series are non-stationary with some 
linear combinations. In particular, among the non-stationary variables of the same order I(1), this test is used to check the existence of a longrun equilibrium relationship based on lags period. The Johansen co-integration test is as follows:

$$
Y_{t}=\mu+A_{1} y_{t-1}+\ldots+A_{p} y_{t-1}+\varepsilon_{t}
$$

where $Y_{t}=$ vector of variables assuming they are integrated in order 1.

The model in equation (3) can also be written as follows:

$$
\Delta y_{t}=\mu+\Pi y_{t-1}+\sum_{i=1}^{p-1} \Gamma_{t} \Delta y_{t-1} \ldots+\varepsilon_{t}
$$

where

$$
\Delta y_{t}=\sum_{i=1}^{p} A_{i}-1 \text { and } \Gamma_{i}=-\sum_{j=i+1}^{p} A_{j} .
$$

If the matrix $\Pi$ is reduced to the rank equal to $r$ less than $n$, it will have $n$-by- $r$ matrices. In particular, $\alpha$ and $\beta$ have the same rank of $r$ in such a way that $\Pi$ is equal to $\alpha \beta^{\prime}$ and $\beta^{\prime} y$, which would be stationary. In this relation, $r$ is the number of cointegrating relations. Whereas, $\alpha$ and $\beta$ are the tuning parameters in vector error corrections (VEC) model. There are two types of probability ratio tests (trace and maximum eigenvalue) of significance that are used in the Johansen cointegration approach.

$$
\begin{aligned}
& J_{\text {trace }}=-T \sum_{i=r+1}^{n} \operatorname{In}\left(1-\hat{\lambda}_{i}\right), \\
& J_{\max }=-T \operatorname{In}\left(1-\hat{\lambda}_{r+1}\right),
\end{aligned}
$$

where $T$ - the size of sample; $\lambda_{i}$ - the $i$-th largest canonical correlation.

When testing the null hypothesis, the trace test will measure the presence of $r$ cointegrating vectors against the alternative hypothesis indicating the presence of $n$ cointegrating vectors. The max eigenvalue value test will measure the presence of $\mathrm{r}$ cointegrating vectors against the alternative hypothesis indicating the presence of $(r+1)$ cointegrating vectors. Johansen and Juselius tables provide the critical value for trace and max eigenval- ue tests. Although the Johansen method is usually used in a setting where all variables in the system are I (1), Johansen points out that the order of integration of the variables in the system should be tested before applying the test.

\subsubsection{Fully modified ordinary least squares (FMOLS)}

FMOLS is a technique that was developed by Phillips and Hansen (1990) and has many advantages. It is an estimator that uses a semi-parametric correction to remove the problems arising from the long-run correlation between the co-integration equation and the innovations of the random regression. It uses kernel estimators for inappropriate parameters that affect the asymptotic distribution of the OLS estimator. FMOLS adjusts the OLS to ignores the problem of serial correlation and endogeneity in the regression caused by a co-integration relationship (Pasha \& Ramzan, 2019). FMOLS is recommended if all the variables are stationary after the first difference and at the same time co-integrated (Shaari et al., 2016). This study uses FMOLS as there is a co-integration relationship between the study variables and they are series I(1). Therefore, the FMOLS is defined after calculating all variables based on the percentage change as follows:

$$
\begin{aligned}
& \% \Delta(I N V)_{t}=\beta_{0}+\beta_{1} \% \Delta(S C)_{t}+ \\
& +\beta_{2} \% \Delta(D U M)_{t}+\beta_{3} \% \Delta(G D P)_{t}+ \\
& +\beta_{4} \% \Delta(I M P)_{t}+\beta_{5} \% \Delta(L R)_{t}+ \\
& +\beta_{6} \% \Delta(E X P)_{t}+\beta_{7} \% \Delta(I N T)_{t}+ \\
& +\beta_{8} \% \Delta(F A C)_{t}+\varepsilon_{t},
\end{aligned}
$$

where $\% \Delta(I N V)_{t}$ - the percentage change in a gross capital formation index in $t$ time; $\% \Delta$ (SC) $t$ - the percentage change in the corruption score in $t$ time; $\% \Delta(D U M)_{t}$ - the percentage change in the war dummy variable in $t$ time; $\% \Delta(G D P)_{t}-$ the percentage change in the growth of domestic product at market prices in $t$ time; $\% \Delta(I M P)_{t}$ - the percentage change in imports in $t$ time; $\% \Delta(L R)$ t the percentage change in domestic revenue in $t$ time; $\% \Delta(E X P)_{t}$ - the percentage change in current expenditure in $t$ time; $\% \Delta(I N T)_{t}$ - the percentage change in weighted average interest on credit and loan facilities in $t$ time; $\% \triangle(F A C)_{t}$ - the percentage change in credit facilities in $t$ time, $\beta$ - coefficient, $\varepsilon_{t}$ - the error term. 
The robustness of the corruption effect can be checked by replacing another variable that measures corruption. This variable is the Corruption Rating Index (RA) in equation (9) instead of the corruption score (SC) in equation (8) as follows:

$$
\begin{aligned}
& \% \Delta(I N V)_{t}=\beta_{0}+\beta_{1} \% \Delta(R A)_{t}+ \\
& +\beta_{2} \% \Delta(D U M)_{t}+\beta_{3} \% \Delta(G D P)_{t}+ \\
& +\beta_{4} \% \Delta(I M P)_{t}+\beta_{5} \% \Delta(L R)_{t}+ \\
& +\beta_{6} \% \Delta(E X P)_{t}+\beta_{7} \% \Delta(I N T)_{t}+ \\
& +\beta_{8} \% \Delta(F A C)_{t}+\varepsilon_{t},
\end{aligned}
$$

where $\% \Delta(R A)_{t}$ - the percentage change in the corruption rank in $t$ time.

\section{RESULTS}

This paper first investigates the presence of unit roots in the variables by the ADF and PP tests. The results of unit root tests are shown in Table 2; Panel A reports that all tested variables (GDP, $I N V, F A C, D U M, S C$ ) in their percent forms are non-stationary but achieve stability only after the first difference in Panel B. This means that any shocks to the variables will last for a long time, and this will affect the measurement of the impact of variables on investment when grouped together in the long run. To address this issue, this paper (see Table 3) applied Johansen's co-integration to assess the existence of a long-term relationship between variables.

The results of the Johansen co-integration tests shown in Table 3 demonstrate that the Trace test indicates the 5 co-integrating equations, and the Max-eigenvalue test indicates 4 co-integrating equation at the 5\% level in Panel A and B, respectively. These results confirm that there is a longterm equilibrium relationship for co-integration tests. Therefore, to obtain more stable results, this study estimates the long-term relationship between investment in Jordan and independent variables based on the FMOLS model.

Table 4 provides the estimate of the Fully Modified Ordinary Least Square (FMOLS) model for investment. The FMOLS model result demonstrates that adjusted R-square is $64.78 \%$, which indicates that the explanatory variables applied in this mod-

\begin{tabular}{|c|c|c|c|c|}
\hline \multirow{2}{*}{ Variables } & \multicolumn{2}{|c|}{ Augmented Dickey-Fuller test statistic } & \multicolumn{2}{|c|}{ Phillips-Perron test statistic } \\
\hline & Intercept & Trend & Intercept & Trend \\
\hline \multicolumn{5}{|c|}{ Panel A: Level } \\
\hline \multirow{2}{*}{ Investment (INV) } & -5.400268 & -5.628443 & -5.477465 & -5.667325 \\
\hline & 0.0001 & 0.0003 & 0.0001 & 0.0003 \\
\hline \multirow{2}{*}{ Corruption Score (SC) } & -0.568540 & -1.818524 & -0.509606 & -1.803887 \\
\hline & 0.8640 & 0.6721 & 0.8766 & 0.6793 \\
\hline \multirow{2}{*}{ Corruption Rank (RA) } & -5.481969 & -5.366154 & -10.26424 & -9.969766 \\
\hline & 0.0001 & 0.0007 & 0.0000 & 0.0000 \\
\hline \multirow{2}{*}{ War Dummy (DUM) } & -2.088932 & -2.461949 & -2.237454 & -2.511833 \\
\hline & 0.2501 & 0.3433 & 0.1977 & 0.3207 \\
\hline \multirow{2}{*}{ Gross Domestic Product (GDP) } & -3.589388 & -3.265481 & -3.514552 & -3.453500 \\
\hline & 0.0117 & 0.0921 & 0.0140 & 0.0621 \\
\hline \multirow{2}{*}{ Imports (IM) } & -4.114376 & -4.158714 & -4.125087 & -4.143423 \\
\hline & 0.0031 & 0.0131 & 0.0030 & 0.0136 \\
\hline \multirow{2}{*}{ Local Revenues (LR) } & -5.400268 & -5.628443 & -5.477465 & -5.667325 \\
\hline & 0.0001 & 0.0003 & 0.0001 & 0.0003 \\
\hline \multirow{2}{*}{ Current Expenditure (EXP) } & -4.569915 & -4.581042 & -4.639387 & -4.649624 \\
\hline & 0.0009 & 0.0047 & 0.0008 & 0.0040 \\
\hline \multirow{2}{*}{ Interest } & -2.075049 & -2.782613 & -2.018911 & -2.907113 \\
\hline & 0.2555 & 0.2137 & 0.2776 & 0.1736 \\
\hline \multirow{2}{*}{ Credit Facilities (FAC) } & -2.744634 & -2.729712 & -2.683984 & -2.644436 \\
\hline & 0.0778 & 0.2322 & 0.0878 & 0.2647 \\
\hline
\end{tabular}
el can explain $64.78 \%$ in Jordanian investment. Table 4 demonstrates that GDP, IMP, LR and EXP proved to be statistically significant at the $1 \%$ level,

Table 2. The results of augmented Dickey-Fuller and Phillips-Perron tests 
Table 2 (cont.). The results of augmented Dickey-Fuller and Phillips-Perron tests

\begin{tabular}{|c|c|c|c|c|}
\hline \multirow{2}{*}{ Variables } & \multicolumn{2}{|c|}{ Augmented Dickey-Fuller test statistic } & \multicolumn{2}{|c|}{ Phillips-Perron test statistic } \\
\hline & Intercept & Trend & Intercept & Trend \\
\hline \multicolumn{5}{|c|}{ Panel B: First difference } \\
\hline \multirow{2}{*}{ Investment (INV) } & -7.202037 & -7.119019 & -11.81160 & -11.65471 \\
\hline & 0.0000 & 0.0000 & 0.0000 & 0.0000 \\
\hline \multirow{2}{*}{ Corruption Score (SC) } & -6.044230 & -6.109461 & -6.044004 & -6.109461 \\
\hline & 0.0000 & 0.0001 & 0.0000 & 0.0001 \\
\hline \multirow{2}{*}{ Corruption Rank (RA) } & -7.243806 & -7.093119 & -17.96206 & -17.89995 \\
\hline & 0.0000 & 0.0000 & 0.0001 & 0.0000 \\
\hline \multirow{2}{*}{ War Dummy (DUM) } & -5.385165 & -5.399257 & -5.385165 & -5.399257 \\
\hline & 0.0001 & 0.0006 & 0.0001 & 0.0006 \\
\hline \multirow{2}{*}{ Gross Domestic Product (GDP) } & -7.951089 & -7.848677 & -16.37725 & -21.17667 \\
\hline & 0.0000 & 0.0000 & 0.0000 & 0.0000 \\
\hline \multirow{2}{*}{ Imports (IM) } & -7.506424 & -5.647859 & -11.91938 & -11.34737 \\
\hline & 0.0000 & 0.0004 & 0.0000 & 0.0000 \\
\hline \multirow{2}{*}{ Local Revenues (LR) } & -10.33556 & -10.22318 & -11.12878 & -10.98957 \\
\hline & 0.0000 & 0.0000 & 0.0000 & 0.0000 \\
\hline \multirow{2}{*}{ Current Expenditure (EXP) } & -6.828664 & -6.711166 & -12.89835 & -12.70901 \\
\hline & 0.0000 & 0.0000 & 0.0000 & 0.0000 \\
\hline \multirow{2}{*}{ Interest (Simon et al.) } & -3.398823 & -3.976179 & -3.401537 & -3.987008 \\
\hline & 0.0187 & 0.0490 & 0.0186 & 0.0471 \\
\hline \multirow{2}{*}{ Credit Facilities (FAC) } & -5.351349 & -5.283321 & -7.692937 & -7.478737 \\
\hline & 0.0001 & 0.0009 & 0.0000 & 0.0000 \\
\hline
\end{tabular}

Table 3. The results of Johansen's co-integration tests

\begin{tabular}{|c|c|c|c|c|}
\hline \multicolumn{5}{|c|}{ Panel A: Unrestricted Co-integration rank test (Trace) } \\
\hline Hypothesized No. of CE(s) & Eigenvalue & Trace stat. & 0.05 Critical value & Prob.** \\
\hline None * & 0.999858 & 764.4390 & 239.2354 & 0.0000 \\
\hline At most $1 *$ & 0.994836 & 489.7085 & 197.3709 & 0.0001 \\
\hline At most $2 *$ & 0.972119 & 326.4589 & 159.5297 & 0.0000 \\
\hline At most $3 *$ & 0.934290 & 215.4849 & 125.6154 & 0.0000 \\
\hline At most $4^{*}$ & 0.826501 & 131.0871 & 95.75366 & 0.0000 \\
\hline At most $5^{*}$ & 0.658650 & 76.78793 & 69.81889 & 0.0125 \\
\hline At most 6 & 0.521889 & 43.46768 & 47.85613 & 0.1216 \\
\hline At most 7 & 0.398753 & 20.59237 & 29.79707 & 0.3835 \\
\hline At most 8 & 0.130872 & 4.821136 & 15.49471 & 0.8275 \\
\hline At most 9 & 0.015140 & 0.472928 & 3.841466 & 0.4916 \\
\hline
\end{tabular}

Panel B: Unrestricted Co-integration Test (Maximum Eigenvalue)

\begin{tabular}{|c|c|c|c|c|}
\hline Hypothesized No. of CE(s) & Eigenvalue & Max-eigen Stat. & 0.05 Critical value & Prob.** \\
\hline None * & 0.999858 & 274.7306 & 64.50472 & 0.0001 \\
\hline At most $1^{*}$ & 0.994836 & 163.2496 & 58.43354 & 0.0000 \\
\hline At most $2^{*}$ & 0.972119 & 110.9739 & 52.36261 & 0.0000 \\
\hline At most $3 *$ & 0.934290 & 84.39784 & 46.23142 & 0.0000 \\
\hline At most $4^{*}$ & 0.826501 & 54.29915 & 40.07757 & 0.0007 \\
\hline At most 5 & 0.658650 & 33.32025 & 33.87687 & 0.0581 \\
\hline At most 6 & 0.521889 & 22.87531 & 27.58434 & 0.1789 \\
\hline At most 7 & 0.398753 & 15.77124 & 21.13162 & 0.2385 \\
\hline At most 8 & 0.130872 & 4.348208 & 14.26460 & 0.8209 \\
\hline At most 9 & 0.015140 & 0.472928 & 3.841466 & 0.4916 \\
\hline
\end{tabular}

Note: ${ }^{*}$ indicate statistical significance at $1 \%$. 
while INT, DUM, and CS are significant at the 5\% confidence level. The first two variables in Table 4 relate to the administrative aspect and the political aspect. The administrative aspect is related to corruption through the Corruption Score Index (SC), while the political aspect is related to the wars in the region and neighboring countries (DUM). For the first variable, which is corruption, this paper finds that its effect is negative and statistically significant ( $t$-stat. 0.177$)$ at the $5 \%$ level. This means that Jordan is suffering from a decline in administrative work, increased bureaucracy, and delays in investor transactions. Consequently, this negatively affected investment in Jordan. This result is consistent with the result of Mauro (1995), Li et al. (2000), and Drebee et al. (2021). Looking at the coefficient in the Dummy war variable, this study finds that it is positive (0.05) and statistically significant (t-stat. 2.09) at the 5\% level. This indicates the transfer of investors and their capital from those countries that were exposed to the war and came to Jordan. Thus, this had a positive impact on investment in Jordan. This finding supports the result of Murad and Alshyab (2019) who find that external political instability has a positive effect in border countries.

The gross domestic product (GDP) has a positive effect and is statistically significant at the $1 \%$ level, which is an expected result. This implies that an increase in GDP affects the presence of investment in a positive way. The GDP coeffi- cient is 1.5 and it is the highest amongst the variables. This result indicates that a $1.0 \%$ increase in GDP in Jordan will lead to a $1.5 \%$ increase in investment presence. Similarly, the investment is positively and significantly affected by the imports (IMP). Both previous results are confirmed by previous studies such as Salahuddin et al. (2009), Rodrik (1999), Alguacil and Orts (2003), Ucan (2014), Duruechi and Ojiegbe (2015), Rani and Batool (2016). They pointed out that imports, in particular, can play a role in promoting economic growth and investment through the import of ideas and intermediate goods.

It can be seen that $L R$ positively and statistically affects investment, while EXP negatively and statistically affects investment in Jordan. The $L R$ coefficient is 0.80 , while the EXP coefficient is -1.166 . This means that if domestic revenue increases by $1 \%$, this will lead to a $0.80 \%$ increase in investment. Based on the data of the CBJ website, $t$ is important to note that $70 \%$ of local revenues come from taxes, whether sales taxes or income taxes. Therefore, despite the positive impact of this factor, it adversely affects citizens and their consumption ability, which negatively affects aggregate demand. Thus, one needs to be cautious in interpreting this factor. On the other hand, if EXP increases by $1 \%$, the investment will decrease by $1.166 \%$. This means that the current government expenditure

Table 4. The effect of various independent variables on Jordanian investment

\begin{tabular}{|c|c|c|c|c|}
\hline \multirow{3}{*}{$\begin{array}{c}\text { Dependent Variable } \\
\text { Independent Variables }\end{array}$} & \multicolumn{4}{|c|}{ Investment } \\
\hline & \multicolumn{4}{|c|}{ Fully Modified Ordinary Least Square (FMOLS) } \\
\hline & Coefficient & Std. Error & t-Statistic & Prob. \\
\hline Constant & $0.220982 * *$ & 0.113198 & $(1.95)$ & 0.0632 \\
\hline $\mathrm{CS}$ & $-0.177831^{* *}$ & 0.083229 & $(-2.14)$ & 0.0435 \\
\hline DUM & $0.052332 * *$ & 0.024996 & $(2.09)$ & 0.0475 \\
\hline GDP & $1.500205^{* * *}$ & 0.372298 & $(4.03)$ & 0.0005 \\
\hline IMP & $0.600423 * * *$ & 0.115940 & $(5.18)$ & 0.0000 \\
\hline LR & $0.801638^{* * *}$ & 0.120025 & $(6.68)$ & 0.0000 \\
\hline EXP & $-1.166021^{* * *}$ & 0.155935 & $(-7.48)$ & 0.0000 \\
\hline INT & $-1.902810 * *$ & 0.910984 & $(-2.09)$ & 0.0480 \\
\hline FAC & -0.013610 & 0.163621 & $(-0.08)$ & 0.9344 \\
\hline R-squared & $\% 73.87$ & \multicolumn{2}{|c|}{ Mean dependent var } & 0.085577 \\
\hline Adjusted R-squared & $\% 64.78$ & \multicolumn{2}{|c|}{ S.D. dependent var } & 0.186052 \\
\hline S.E. of regression & 0.110419 & \multicolumn{2}{|c|}{ Sum squared resid } & 0.280425 \\
\hline Long-run variance & \multicolumn{4}{|c|}{0.002007} \\
\hline
\end{tabular}

Note: $* * *, * *$, and $*$ indicate statistical significance at $1 \%, 5 \%$, and $10 \%$ levels, respectively. 
Table 5. Robustness analysis: corruption rank effect on Jordanian investment

\begin{tabular}{|c|c|c|c|c|}
\hline \multirow{3}{*}{$\begin{array}{c}\text { Dependent variable } \\
\text { Independent Variables }\end{array}$} & \multicolumn{4}{|c|}{ Investment } \\
\hline & \multicolumn{4}{|c|}{ Fully modified ordinary least square (FMOLS) } \\
\hline & Coefficient & Std. Error & t-Statistic & Prob. \\
\hline Constant & 0.009343 & 0.060388 & $(0.15)$ & 0.8784 \\
\hline RA & $-0.309108^{* * *}$ & 0.067515 & $(-4.58)$ & 0.0001 \\
\hline DUM & $0.069291^{* * *}$ & 0.019613 & (3.53) & 0.0018 \\
\hline GDP & $2.139147^{* * *}$ & 0.297243 & $(7.20)$ & 0.0000 \\
\hline IMP & $0.806840 * * *$ & 0.083180 & $(9.70)$ & 0.0000 \\
\hline LR & $0.616112^{* * *}$ & 0.096949 & $(6.36)$ & 0.0000 \\
\hline EXP & $-1.126225^{* * *}$ & 0.143757 & $(-7.83)$ & 0.0000 \\
\hline INT & -0.341619 & 0.570385 & $(-0.60)$ & 0.5551 \\
\hline FAC & 0.082800 & 0.150682 & $(0.55)$ & 0.5880 \\
\hline R-squared & $\% 76.32$ & \multicolumn{2}{|c|}{ Mean dependent var } & 0.085577 \\
\hline Adjusted R-squared & $\% 68.09$ & \multicolumn{2}{|c|}{ S.D. dependent var } & 0.186052 \\
\hline S.E. of regression & 0.105102 & \multicolumn{2}{|c|}{ Sum squared resid } & 0.254070 \\
\hline Long-run variance & \multicolumn{4}{|c|}{0.001713} \\
\hline
\end{tabular}

Note: $* * *, * *$, and $*$ indicate statistical significance at $1 \%, 5 \%$ and $10 \%$ levels, respectively.

constitutes a large part of the budget, and it is likely that it goes to salaries and does not serve investment in Jordan. Therefore, there must be a plan to rationalize government spending and direct it towards capital spending in a way that serves infrastructure and investment.

Table 4 shows that INT has a negative and significant impact on investment in Jordan. In particular, the interest rate (INT) coefficient is -1.90 and significant at the level of $5 \%$. This result is consistent with the financial theory, which indicates that higher interest rates will lead to higher financing costs, thus avoiding investors to borrow and reduce investment. For credit facilities $(F A C)$, it is negative but insignificant. This implies that the credit facilities provided by Jordanian banks are not directed towards productive sectors, but rather for consumer loans such as for purchasing of real estate, cars and marriage expenses. Therefore, these credit facilities do not have a positive impact on investment, but generally, it has a negative impact.

\section{ROBUSTNESS ANALYSIS}

The robustness of the corruption result to the choice of index can be checked by replacing the corruption score index with the corruption rank index $(R A)$. Thus, whereas FMOLS are used to understand determinants of investment in Jordan (see Table 4), the same model is used to recognize determinants of investment in Jordan by replacing the $R A$ variable with the $S C$ variable (see Table 5). Inspection of the $R A$ factor is larger in Table 5 than the $S C$ factor in Table 4. This strongly indicates that the corruption factor plays an important role in limiting investment in Jordan, and the corruption factor represented by $R A$ is the best for determining investment in Jordan because $R A$ is statistically significant ( $t$-stat. 4.58$)$ at the $1 \%$ level. In addition, adjusted R-square in Table 5 is larger $68.09 \%$ than adjusted R-square $64.78 \%$ in Table 4 , indicating that the explanatory variables applied in this model have a $68.09 \%$ greater explanatory power in Jordanian investment.

Recall that for the determinants of investment in Table 4, there are positive and statistically significant for four factors (GDP, IMP, $L R$, and $D U M$ ), while negative and statistically significant in determining investment for three factors (EXP, INT, and SC). However, one factor, FAC, has no statistical significance for investment in Jordan. Table 5 shows relatively similar results, but two factors related to monetary policy are not statistically significant, FAC and INT. This confirms that monetary policy in Jordan needs to be reviewed by reducing INT and directing $F A C$ towards productive sectors. 


\section{CONCLUSION}

This study examines the impact of two important factors, namely corruption and political instability, as well as macroeconomic factors, on investment in Jordan over the period 1987-2020. Using the FMOLS model, this paper provides new evidence on the impact of corruption indices and wars in the region on investment. The results of the study showed that the corruption, as measured by two indicators, whether scores or rank, has a negative and statistically significant impact on investment. Therefore, decision makers in Jordan need to reconsider transparency standards, further simplify procedures and reduce transaction costs for investors. In addition, this paper shows that the wars in neighboring countries had a positive and statistically significant impact on investment in Jordan. This may be due to the migration of investors and their capital from the Gulf countries that have been subjected to war and political instability to Jordan.

Macroeconomic factors showed statistically significant results. In particular, a positive and statistically significant effect was found for growth domestic product and imports on investment. For fiscal policy in Jordan, local revenues had a positive effect and statistical significance, while current government expenditure had a negative and statistically significant effect. However, care must be taken in interpreting the local revenue factor as most of them are taxes. The recommendation to increase local revenues implies an increase in taxes, which will negatively affect citizens' ability to consume, thus leading to a decrease in aggregate demand. On the other hand, the negative impact of current government spending on investment leads us to a simple conclusion that a large part of government spending goes toward salaries, benefits, and hospitality. Therefore, rationalizing current government spending is an urgent necessity to increase investment. Looking at monetary policy, the results showed that the interest rate has an inverse and statistically significant effect on investment. This is due to the strict policy of the Central Bank of Jordan, which was reflected in the costs of financing, so investment decreased. On the other hand, the credit facilities were not statistically significant as $50 \%$ of these facilities were not intended for productive sectors.

\section{AUTHOR CONTRIBUTIONS}

Conceptualization: Omar K. Gharaibeh, Buthiena Kharabsheh.

Data curation: Omar K. Gharaibeh, Buthiena Kharabsheh.

Formal analysis: Omar K. Gharaibeh, Buthiena Kharabsheh.

Funding acquisition: Omar K. Gharaibeh, Buthiena Kharabsheh.

Investigation: Omar K. Gharaibeh, Buthiena Kharabsheh.

Methodology: Omar K. Gharaibeh, Buthiena Kharabsheh.

Project administration: Omar K. Gharaibeh, Buthiena Kharabsheh.

Resources: Omar K. Gharaibeh, Buthiena Kharabsheh.

Software: Omar K. Gharaibeh, Buthiena Kharabsheh.

Supervision: Omar K. Gharaibeh, Buthiena Kharabsheh.

Validation: Omar K. Gharaibeh, Buthiena Kharabsheh.

Visualization: Omar K. Gharaibeh, Buthiena Kharabsheh.

Writing - original draft: Omar K. Gharaibeh, Buthiena Kharabsheh.

Writing - review \& editing: Omar K. Gharaibeh, Buthiena Kharabsheh.

\section{REFERENCES}

1. Abu-Lila, Z. M. (2021).

Determinants of Investment in the Jordanian Productive Sectors. The Journal of Asian Finance, Economics and Business, 8(4), 635-641. https://doi.org/10.13106/ jafeb.2021.vol8.no4.0635
2. Acemoglu, D., \& Verdier, T. (1998). Property rights, corruption and the allocation of talent: a general equilibrium approach. The Economic Journal, 108(450), 1381-1403. https://doi. org/10.1111/1468-0297.00347.
3. Afolabi, L., \& Abu Bakar, N. (2016). Causal link between trade, political instability, FDI, and economic growth: Nigeria evidence. Journal of Economics Library, 3(1), 100-110. Retrieved 
from http://www.kspjournals.org/ index.php/JEL/article/view/635

4. Alesina, A., Özler, S., Roubini, N., \& Swagel, P. (1996). Political instability and economic growth. Journal of Economic Growth, 1(2), 189-211. https://doi.org/10.3386/ w4173

5. Alguacil, M., \& Orts, V. (2003). Inward foreign direct investment and imports in Spain. International Economic Journal, 17(3), 1938. Retrieved from https:// www.tandfonline.com/doi/ abs/10.1080/10168730300000002

6. Asteriou, D., \& Price, S. (2001). Political uncertainty and economic growth: UK time-series evidence. Scottish Journal of Political Economy, 48(4), 383-399. https:// doi.org/10.1111/1467-9485.00205

7. Bader, M., \& Malawi, A. I. (2010). The impact of interest rate on investment in Jordan: a cointegration analysis. Economics and Administration, 24(1), 199-209. https://doi.org/10.4197/Eco.24-1.6

8. Beck, P. J., \& Maher, M. W. (1986). A Comparison of Bribery and Bidding in Thin Markets. Economics Letters, 20(1), 1-5. https://doi.org/10.1016/01651765(86)90068-6

9. Bibi, S., Khan, U. A., \& Bibi, A. (2012). Determinants of investment in Pakistan. Academic Research International, 2(2), 517524. Retrieved from http://www. savap.org.pk/journals/ARInt./ Vol.2(2)/2012(2.2-57).pdf

10. Chung, W. (2001). Identifying technology transfer in foreign direct investment influence of industry contiotions and investing firm motive. Journal of International Business Studies, 32(2), 211-229. Retrieved from https://ideas.repec.org/a/pal/jintbs/ v32y2001i2p211-229.html

11. Dabour, N. (2000). The role of foreign direct investment (FDI) in development and growth in OIC member countries. Journal of Economic Cooperation, 21(3), 27e55. Retrieved from https:// sesricdiag.blob.core.windows.net/ sesric-site-blob/files/article/188. pdf
12. Dickey, D. A., \& Fuller, W. A. (1979). Distribution of the estimators for autoregressive time series with a unit root. Journal of the American Statistical Association, 74(366a), 427-431. https://doi.org/ 10.1080/01621459.1979.10482531

13. Drabek, Z., \& Payne, W. (2002). The impact of transparency on foreign direct investment. Journal of Economic Integration, 17(4), 777-810. Retrieved from https:// www.jstor.org/stable/23000835

14. Drebee, H. A., Razak, N. A. A., \& Brisam, A. A. (2021). What are the Determinants of Investment in the Iraqi Agricultural Sector? Paper presented at the IOP Conference Series: Earth and Environmental Science, vol.732. https://doi.org/10.1088/17551315/735/1/012038

15. Duruechi, A. H., \& Ojiegbe, J. N. (2015). Determinants of Investments in the Nigerian Economy: An Empirical Approach (1990-2013). International Journal of Financial Research, 6(4), 217227. https://doi.org/10.5430/ijfr. v6n4p217

16. Dunning, J. H. (1973). The determinants of international production. Oxford Economic Papers, 25(3), 289-336. https:// www.jstor.org/stable/2662317.

17. Gould, D. J., \& Amaro-Reyes, J. A. (1983). The effects of corruption on administrative performance. World Bank Staff Working Paper, 580(2514). https:// agris.fao.org/agris-search/search. do? recordID=US2012423148.

18. Hansen, B. E., \& Phillips, P. C. (1990). Estimation and inference in models of cointegration: A simulation study. Advances in Econometrics, 8, 225-248. Retrieved from http://korora.econ. yale.edu/phillips/pubs/art/a069. pdf

19. Heidenheimer, A. J., Johnston, M., \& Le Vine, V. T. (1989). Political Corruption: A Handbook. NJ.: Transaction Books. Retrieved from https://doi. org/10.4324/9781315126647

20. Huang, C. J. (2016). Is corruption bad for economic growth?
Evidence from Asia-Pacific countries. North American Journal of Economics and Finance, 35, 247-256. https://doi.org/10.1016/j. najef.2015.10.013

21. Huntington, S. P. (2002). Modernization and corruption. In Political Corruption: Concepts and Contexts (pp. 253-263). Routledge.

22. Jaara, B. O. A. (2021). Political Instability and Banks Performance in the Light of Arab Spring: Evidence from GCC Region. International Journal of Financial Research, 12(3), 284-299. https:// doi.org/10.5430/ijfr.v12n3p284

23. Jiang, T., \& Nie, H. (2014). The stained China miracle: Corruption, regulation, and firm performance. Economics Letters, 123(3), 366-369. https://doi.org/10.1016/j.econlet.2014.03.026

24. Johansen, S. (1988). Statistical analysis of cointegration vectors. Journal of Economic Dynamics and Control, 12(2-3), 231-254. https://doi.org/10.1016/01651889(88)90041-3

25. Johansen, S., \& Juselius, K. (1990). Maximum likelihood estimation and inference on cointegration - with applications to the demand for money. Oxford Bulletin of Economics and Statistics, 52(2), 169-210. Retrieved from http://ecsocman.hse.ru/rubezh/ msg/18010030.html

26. Leff, N. H. (1964). Economic development through bureaucratic corruption. American Behavioral Scientist, 8(3), 8-14. https://doi. org/10.1177/000276426400800303.

27. Li, Hongyi, Lixin, C. Xu, \& Heng-fu, Zou. (2000). Corruption, Income Distribution, and Growth. Economics and Politics, 12(2), 155 82. https://doi.org/10.1111/14680343.00073

28. Lui, F.T. (1985). An equilibrium queuing model of bribery. Journal of Political Economy, 93(4), 760-781. https://doi. org/10.1086/261329

29. Mauro, P. (1995). Corruption and Growth. Quarterly Journal of Economics, 110(3), 681-712. https://doi.org/10.2307/2946696 
30. Mlambo, K., \& Oshikoya, T. W. (2001). Macroeconomic factors and investment in Africa. Journal of African Economies, 10(suppl_2), 12-47. https://doi.org/10.1093/ jae/10.Suppl2.12

31. Mo, P. H. (2001). Corruption and economic growth. Journal of Comparative Economics, 29(1), 66-79. https://doi.org/10.1006/ jcec. 2000.1703

32. Murad, M. S. A., \& Alshyab, N. (2019). Political instability and its impact on economic growth: the case of Jordan. International Journal of Development Issues, 18(3), 366-380. https://doi. org/10.1108/IJDI-02-2019-0036

33. Pasha, A., \& Ramzan, M. (2019). Asymmetric impact of economic value-added dynamics on market value of stocks in Pakistan stock exchange, a new evidence from panel co-integration, FMOLS and DOLS. Cogent Business \& Management, 6(1), 1653544. https://doi.org/10.1080/23311975. 2019.1653544

34. Pedroni, P. (1996). Fully modified OLS for heterogeneous cointegrated panels and the case of purchasing power parity. Manuscript, Department of Economics, Indiana University, 5, 1-45. Retrieved from https://web. williams.edu/Economics/pedroni/ WP-96-20.pdf

35. Perron, P., \& Phillips, P. C. (1986). Does GNP have a Unit Root? A Reevaluation. Université de Montréal, Département de Science économique et Centre de. Retrieved from https://econpapers. repec.org/paper/mtlmontde/8640. htm

36. Phillips, P. C., \& Perron, P. (1988), Testing for a unit root in time series regression. Biometrika, 75(2), 335-346. https://doi.org/10.1093/ biomet/75.2.335

37. Qureshi, F., Qureshi, S., Vo, X. V., \& Junejo, I. (2021). Revisiting the nexus among foreign direct investment, corruption and growth in developing and developed markets. Borsa Istanbul Review, 21(1), 80-91. https://doi. org/10.1016/j.bir.2020.08.001
38. Rani, K., \& Batool, Z. (2016). Impact of political instability and foreign direct investment on economic development in Pakistan. Asian Economic and Financial Review, 6(2), 83-89. Retrieved from https://ideas.repec.org/a/asi/ aeafrj/v6y2016i2p83-89id1449. html

39. Rock, M. T., \& Bonnett, H. (2004). The comparative politics of corruption: Accounting for the East Asian paradox in empirical studies of corruption, growth and investment. World Development, 32(6), 999-1017. https://doi.org/10.1016/j.worlddev.2003.12.002

40. Rodrik, D. (1999). The new global economy and developing countries: making openness work (Vol. 24). Overseas Development Council Washington, DC.

41. Salahuddin, M., Islam, R., \& Salim, S. A. (2009). Determinants of investment in Muslim developing countries: an empirical investigation. International Journal of Economics and Management, 3(1), 100-129. Retrieved from http://www.ijem.upm.edu.my/ vol3no1/bab08.pdf

42. Shaari, M. S., Abdullah, D. N. C., Alias, N. S., \& Adnan, N. S. M. (2016). Positive and negative effects of research and development. International Journal of Energy Economics and Policy, 6(4), 767-770. Retrieved from https://www.econjournals.com/ index.php/ijeep/article/view/2978

43. Simon, H. A., Dantzig, G. B., Hogarth, R., Plott, C. R., Raiffa, H., Schelling, T. C., Shepsle, K. A., Thaler, R., Tversky, A., \& Winter, S. (1987). Decision making and problem solving. Interfaces, 17(5), 11-31. https://doi.org/10.1287/ inte.17.5.11

44. Sukharev, O. (2021). Investment Function of Economic Growth in Russia. Finance: Theory and Practice, 25(1), 35-50. https://doi. org/10.26794/2587-5671-2021-25$1-35-50$

45. Transparency International. (n.d.). Report corruption. Retrieved from https://www.transparency.org/en/ countries/jordan
46. Ucan, O. (2014). The

Determinants of Investment: Panel Data Analysis of G7 Countries European Scientific Journal, 1(1), 28-35. Retrieved from https://eujournal.org/index.php/esj/article/ view/2807

47. Vernon, R. (1974). The location of economic activity. Economic analysis and the multinational enterprise, 89, 114.

48. Wai, U. T., \& Wong, C.-h. (1982). Determinants of private investment in developing countries. The Journal of Development Studies, 19(1), 19-36. https://doi. org/10.1080/00220388208421848

49. Yousaf, M. M., Hussain, Z., \& Ahmad, N. (2008). Economic evaluation of foreign direct investment in Pakistan. Pakistan Economic and Social Review, 46(1), 37-56. Retrieved from https://pesr. econpu.edu.pk/website/journal/ article/608a63a0458b1/page

50. Zhang, K. H. (2001). How does foreign investment affect economic growth in China? Economics of Transition, 9(3), 679-693. https:// doi.org/10.1111/1468-0351.00095 